\title{
Blue carbon stock of the seagrass meadows of Gulf of Mannar and Palk Bay off Coromandel Coast, south India
}

\author{
P. KALADHARAN ${ }^{1}$, P. U. ZACHARIA ${ }^{1}$, S. THIRUMALAISELVAN ${ }^{2}$, A. ANASUKOYA ${ }^{3}$, \\ LAVANYA RATHEESH ${ }^{1}$ AND S. M. SIKKANDER BATCHA ${ }^{2}$ \\ ${ }^{1}$ ICAR-Central Marine Fisheries Research Institute, Kochi - 682 018, Kerala, India \\ ${ }^{2}$ Mandapam Regional Centre of ICAR-Central Marine Fisheries Research Institute, Mandapam Camp - 623520 \\ Tamil Nadu, India \\ ${ }^{3}$ Krishi Vigyan Kendra of ICAR-Central Marine Fisheries Research Institute, Kavaratti - 682555 \\ U. T. of Lakshadweep, India \\ e-mail: kaladharanep@gmail.com
}

\begin{abstract}
Blue carbon stock of the seagrass meadows of Gulf of Mannar and Palk Bay, off Coromandel Coast, south India, were computed from the organic carbon content and dry bulk densities of sediment core taken from the seagrass meadows of these two ecosystems. The Gulf of Mannar (GoM) and Palk Bay (PB) harbour 13 seagrass species dominated by Cymodocea serrulata and Syringodium isoetifolium. The soil carbon density of both GoM and PB were higher in subsurface cores. The blue carbon stock of seagrass meadows of the GoM was estimated as $0.001782 \mathrm{Tg}$ and that of PB as $0.043996 \mathrm{Tg}$. The estimated value of blue carbon stored in seagrass meadows of GoM was 17820 US\$ and that of PB was 43,99,682 US\$. The results of this study are discussed in the light of climate change mitigation, emphasising the need to conserve these underwater meadows.
\end{abstract}

Keywords: Blue carbon sink, Climate change, Coromandel Coast, Organic carbon, Seagrass meadows

Ecosystems capable of absorbing and storing large amounts of carbon dioxide are known as carbon sinks and the term blue carbon refers to the carbon stored in sediments from coastal ecosystems such as seagrass meadows, mangrove forests and salt marshes. Coastal ecosystems become more relevant for carbon sink as two-third of the earth's surface is covered by seawater. Seagrass meadows are among the most important coastal marine ecosystems for long term carbon storage and conditioning of coastal waters. Seagrasses sequester atmospheric $\mathrm{CO}_{2}$ through photosysnthesis and deposit in the sediment. Though seagrass meadows occupy less than $0.2 \%$ of the area of the world's oceans, they are estimated to bury 27.4 $\mathrm{Tg} \mathrm{C} \mathrm{yr}^{-1}\left(1\right.$ Terra gram $\left.=1 \times 10^{9} \mathrm{~kg}\right)$ which is roughly equivalent to $10 \%$ of the yearly estimated organic carbon (C org) burial in the oceans (Duarte et al., 2005; Fourqurean et al., 2012). Because of this great potential, good management of seagrass ecosystems assign higher importance for countries to make progress in meeting their target of sustainable development goal 14 (SDG-14) set by the Paris Agreement (UNDESA, 2020).

Detailed review of goods and services offered by seagrass meadows can be gleaned from the works of
Terrados and Borum (2004) and Unsworth and Unsworth (2013). The seagrass meadows are known to serve as antacid to contain ocean acidification as they can sequester dissolved $\mathrm{CO}_{2}$ and enrich the lagoon with oxygen through canopy photosynthesis and storage of blue carbon (12\%) in their underground shoot and root systems. Banerjee et al. (2018) studied a combined air-water flux of $\mathrm{CO}_{2}$ and $\mathrm{CH}_{4}$ from the seagrass meadows of brackishwater Chilika Lake. Growing coastal populations and increasing coastal developments threaten seagrass habitats globally and the decline of seagrass meadows is taking place very rapidly (Waycott et al., 2009; Fourqurean et al., 2012; Kaladharan and Anasukoya, 2019). It is proved with experimental evidence that restoration of seagrass habitat could enhance carbon sequestration in the coastal zone (Greiner et al., 2013). Gulf of Mannar and Palk Bay, off south-east coast of India, harbour 13 species of seagrass plants dominated by Cymodocea serrulata and Syringodium isoetifolium and the seagrass meadows of these regions are constantly undergoing tremendous anthropic pressures causing considerable reduction in seagrass density and coverage (Kannan et al., 1999; Susila et al., 2012; Thangaradjou and Bhatt, 2018). Blue carbon stock of Gulf of Mannar (GoM) and the Palk Bay (PB) were computed according 
to the procedure mentioned in Jones et al. (2005), from the soil carbon density of sediment core samples taken from 14 sites within the Gulf of Mannar and 18 sites within Palk Bay regions, off the Coromandel Coast, southern India, during August-October 2019 (Fig. 1). Sediment samples upto $20 \mathrm{~cm}$ depth were taken in triplicate from each site using a locally fabricated sediment corer (Fig. 2), $1 \mathrm{~m}$ long having $5 \mathrm{~cm}$ lumen dia, to get two cores of $10 \mathrm{~cm}$ interval. Hence from each site, 6 sediment cores $[3$ nos. of Core A (surface core), 0-10 cm and 3 nos. of Core B (subsurface core), 10-20 cm] were obtained. After determining the dry weight and dry bulk density of the cores, organic carbon content $(\mathrm{C} \operatorname{org} \%)$ in the sediment cores were determined according to the standard method of Walkley and Black (1934). Area of seagrass cover in the GoM was obtained from Susila et al. (2012) and that of PB from Tangaradjou et al. (2015).

UNESCO describes the Gulf of Mannar Biosphere Reserve (GoMBR) as one of the world's richest region in marine biodiversity having 4223 species of plants and animals making it "one of the richest coastal regions" in India (UNESCO.ORG). Seagrass, growing as underwater meadows are considered ecosystem engineers due to their higher primary production, carbon and nitrogen



Fig. 2. Locally fabricated corer used for sediment collection

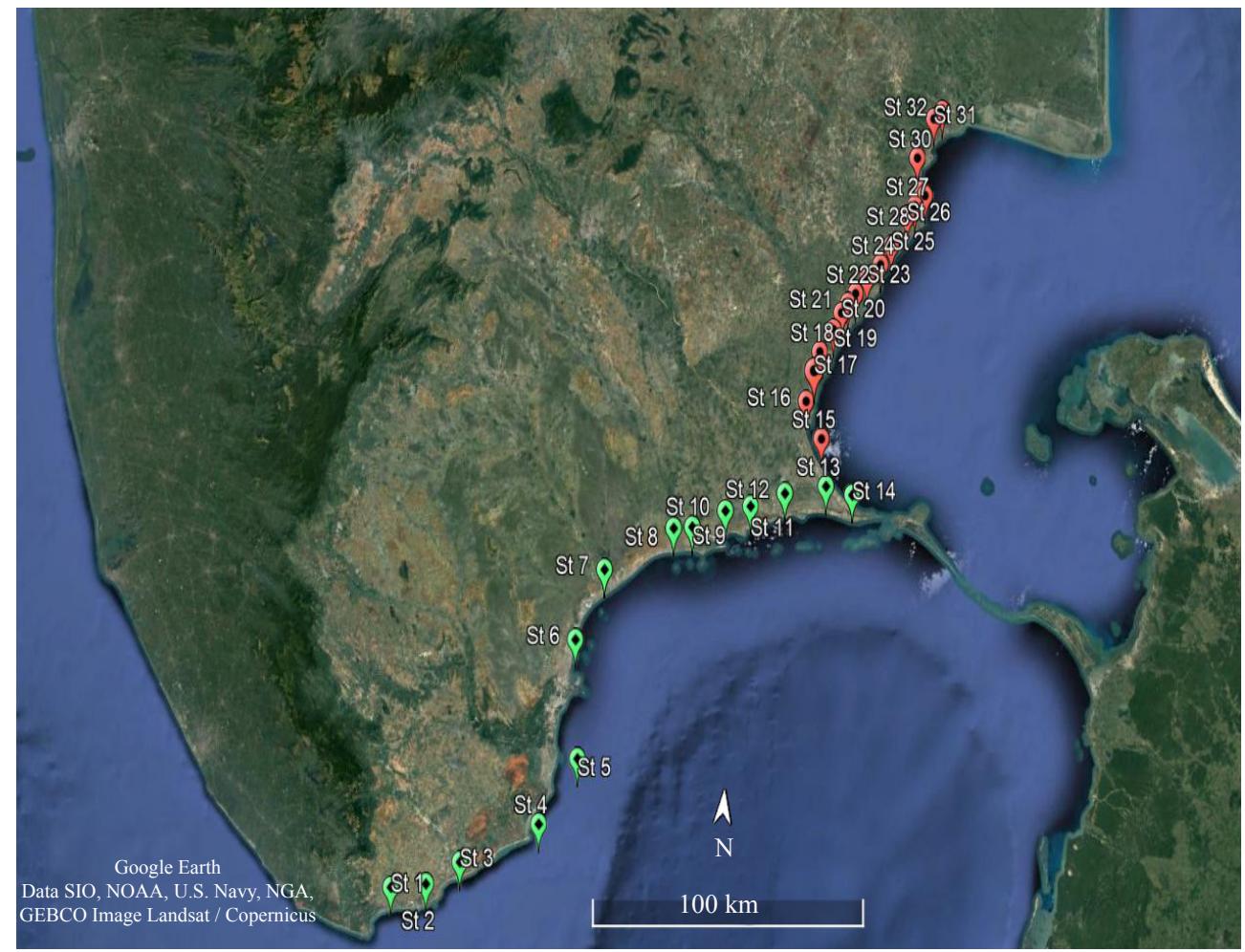

Fig. 1. Map of the study area showing sampling sites in Gulf of Mannar and Palk Bay (Sourced from Google Earth) 
sequestration potential and long term storage of carbon in sediment. The nature of sediment in GoM region except for Valinokkam area was generally coarse to fine sandy while that of PB was fine sand to clayey. The organic carbon content ( $\mathrm{C}$ org) in the sediment cores of GoM region showed a mean value of $0.0965 \pm 0.014 \%$, ranging from $0.02860 .2821 \%$ in core A $(0-10 \mathrm{~cm})$. The mean value was $0.08784 \pm 0.022 \%$, ranging from $0.0286-0.2413 \%$ in the subsurface core B $(10-20 \mathrm{~cm})$. In the Palk Bay region, a higher mean of $0.7147 \pm 0.081 \%$ ranging from 0.2342 $1.297 \%$ was observed in core B, while the surface core A registered a mean of $0.66072 \pm 0.105 \%$ ranging from $0.2342-1.574 \%$. The soil carbon density of coastal sediments along the Palk Bay was found to be higher than that of GoM region (Tables 1 and 2). The reason for the increase in $\mathrm{PB}$ is presumed to be due to higher settlement of seagrass leaf litter and organic matter in the bay regions besides the wider area of seagrass cover. Blue carbon stock of seagrass meadows of $\mathrm{PB}$ was quantified as $0.001782 \mathrm{Tg} \mathrm{C}$ and that of $\mathrm{GoM}$ was estimated to be 0.043996Tg C (Table 3).
Our results are comparable with the available reports (Duarte et al., 2010; Lavery et al., 2013) who opined that for a seagrass area of $300,000 \mathrm{~km}^{2}$, the net community production of seagrass meadows would range from 20.7 to 50.69 $\mathrm{Tg} \mathrm{C} \mathrm{yr}^{-1}$. From Rottnest Island, Australia, Bedulli et al. (2020) derived carbon stocks of $5.1 \pm 0.7 \mathrm{~kg} \mathrm{C}$ org m$^{-2}$ in $0.5 \mathrm{~m}$ thick seagrass soil deposits. Seagrasses of Red Sea seagrass meadows are known to store $3.4 \pm 0.3 \mathrm{~kg} \mathrm{C}$ org m$^{-2}$ in $1 \mathrm{~m}$ thick soil deposit which accumulate at the rate of $6.8 \pm 1.7 \mathrm{~g} \mathrm{C}$ org $\mathrm{m}^{-2} \mathrm{yr}^{-1}$ (Serrano et al., 2018). According to Serrano et al. (2019) the price of blue carbon is fixed at 10 US\$ and hence the blue carbon stored in the seagrass meadows of GoM and PB could be valued at17820 US\$ and 4399682 US\$, respectively.

Even the mildest rate of depletion in seagrass cover can cause the emission of blue carbon from the sink back to the atmosphere. Restoration of habitats for Zostera marina for more than 1700 ha in the coastal bays of Virginia as a model system increased the carbon storage in the coastal sediments considerably (Greiner et al., 2013). Hence the outcome of this study is relevant in the light of climate

Table 1. Study locations, GPS coordinates and soil carbon density ( $\mathrm{SCD}, \mathrm{g} \mathrm{C} \mathrm{cm}{ }^{-2}$ ) of sediment cores from the Gulf of Mannar

\begin{tabular}{|c|c|c|c|c|c|}
\hline Station No. & Study site & GPS coordinates & SCD core $\mathrm{A}\left(\mathrm{g} \mathrm{C} \mathrm{cm}^{-2}\right)$ & SCD core $\mathrm{B}\left(\mathrm{g} \mathrm{C} \mathrm{cm}^{-2}\right)$ & Total for $20 \mathrm{~cm}\left(\mathrm{~g} \mathrm{C} \mathrm{cm}^{-2}\right)$ \\
\hline 1 & Chettikulam Pannaiur & $\begin{array}{l}8^{\circ} 08^{\prime} 50.9 ’ \mathrm{~N} \\
77^{\circ} 37^{\prime} 27.6^{\prime} \mathrm{E}\end{array}$ & 0.0006068 & 0.0007809 & 0.0013877 \\
\hline 2 & Idinthakarai & $\begin{array}{l}8^{\circ} 09^{\prime} 17.5 ” \mathrm{~N} \\
77^{\circ} 44^{\prime} 25.5^{\prime \prime} \mathrm{E}\end{array}$ & 0.0020489 & 0.0012187 & 0.0032676 \\
\hline 3 & Navalady & $\begin{array}{l}8^{\circ} 13^{\prime} 11.5^{\prime \prime} \mathrm{N} \\
77^{\circ} 50^{\prime} 53.2 ” \mathrm{E}\end{array}$ & 0.0046746 & 0.0015427 & 0.0062173 \\
\hline 4 & Manapad & $\begin{array}{l}8^{\circ} 20^{\prime} 20.3 ” \mathrm{~N} \\
78^{\circ} 06^{\prime} 40.4^{\prime \prime} \mathrm{E}\end{array}$ & 0.0031204 & 0.00258 & 0.0057004 \\
\hline 5 & Veerapandiyanpattinam & $\begin{array}{l}8^{\circ} 30^{\prime} 46.7 ’ \mathrm{~N} \\
78^{\circ} 12^{\prime} 51.6^{\prime \prime} \mathrm{E}\end{array}$ & 0.0005377 & 0.001836 & 0.0023737 \\
\hline 6 & Tuticorin Harbour & $\begin{array}{l}8^{\circ} 48^{\prime} 26.4 ” \mathrm{~N} \\
78^{\circ} 10^{\prime} 42.4^{\prime \prime} \mathrm{E}\end{array}$ & 0.0014262 & 0.0004921 & 0.0019183 \\
\hline 7 & Sippikulam & $\begin{array}{l}8^{\circ} 59^{\prime} 27.6 ” \mathrm{~N} \\
78^{\circ} 15^{\prime} 30.9 \text { ' }\end{array}$ & 0.0005177 & 0.0006097 & 0.0011274 \\
\hline 8 & Mookayur & $\begin{array}{l}9^{\circ} 06^{\prime} 58.9{ }^{\prime \prime} \mathrm{N} \\
78^{\circ} 28^{\prime} 51.2 ” \mathrm{E}\end{array}$ & 0.0007699 & 0.0021297 & 0.0028996 \\
\hline 9 & S. Mariyur & $\begin{array}{l}9^{\circ} 07^{\prime} 31.8^{\prime \prime} \mathrm{N} \\
78^{\circ} 32^{\prime} 35.8^{\prime \prime} \mathrm{E}\end{array}$ & 0.0012383 & 0.001036 & 0.0022743 \\
\hline 10 & Valinokkam & $\begin{array}{l}9^{\circ} 10^{\prime} 34.9{ }^{\prime \prime} \mathrm{N} \\
78^{\circ} 39^{\prime} 30.8^{\prime \prime} \mathrm{E}\end{array}$ & 0.0011588 & 0.006222 & 0.0073808 \\
\hline 11 & Ervadi & $\begin{array}{l}9^{\circ} 11^{\prime} 44.4 ” \mathrm{~N} \\
78^{\circ} 44^{\prime} 48.7 ” \mathrm{E}\end{array}$ & 0.0036547 & 0.0014187 & 0.0050734 \\
\hline 12 & Sethukarai & $\begin{array}{l}9^{\circ} 14^{\prime} 19.9 ’ \mathrm{~N} \\
78^{\circ} 50^{\prime} 51.2 ” \mathrm{E}\end{array}$ & 0.002405 & 0.0021682 & 0.0045732 \\
\hline 13 & Puthumadam & $\begin{array}{l}9^{\circ} 16^{\prime} 10.3 ” \mathrm{~N} \\
78^{\circ} 59^{\prime} 05.2 ” \mathrm{E}\end{array}$ & 0.0006021 & 0.0006021 & 0.0012042 \\
\hline \multirow[t]{2}{*}{14} & Sundaramudayan & $\begin{array}{l}9^{\circ} 15^{\prime} 20.7 ’ \mathrm{~N} \\
79^{\circ} 04^{\prime} 31.2 ” \mathrm{E}\end{array}$ & 0.0014192 & 0.0014434 & 0.0028626 \\
\hline & Mean \pm SE & & $0.0017272 \pm 0.0013$ & $0.00172 \pm 0.0014$ & $0.0034472 \pm 0.00202$ \\
\hline
\end{tabular}






\begin{tabular}{|c|c|c|c|c|c|}
\hline Station No. & Study site & GPS coordinates & SCD core A $\left(\mathrm{g} \mathrm{C} \mathrm{cm}^{-2}\right)$ & $\mathrm{SCD}$ core $\mathrm{B}\left(\mathrm{g} \mathrm{C} \mathrm{cm}^{-2}\right)$ & Total for $20 \mathrm{~cm}\left(\mathrm{~g} \mathrm{C} \mathrm{cm}^{-2}\right)$ \\
\hline 15 & Panaikulam & $\begin{array}{l}9^{\circ} 23^{\prime} 08.4 ” \mathrm{~N} \\
78^{\circ} 57^{\prime} 23.1 \text { ' }\end{array}$ & 0.008061 & 0.00934 & 0.017401 \\
\hline 16 & Devipatnam & $\begin{array}{l}9^{\circ} 28^{\prime} 38.99^{\prime \prime} \mathrm{N} \\
78^{\circ} 53,56.2^{\prime \prime} \mathrm{E}\end{array}$ & 0.01317 & 0.02205 & 0.03522 \\
\hline 17 & Thirupalaikudi & $\begin{array}{l}9^{\circ} 32^{\prime} 39.6 ” \mathrm{~N} \\
78^{\circ} 55^{\prime} 13.5^{\prime \prime} \mathrm{E}\end{array}$ & 0.01034 & 0.00909 & 0.01943 \\
\hline 18 & Moreppanai & $\begin{array}{l}9^{\circ} 36^{\prime} 26.9{ }^{\prime \prime} \mathrm{N} \\
78^{\circ} 56^{\prime} 04.5 ” \mathrm{E}\end{array}$ & 0.01379 & 0.01072 & 0.02451 \\
\hline 19 & Pudhupattinam & $\begin{array}{l}9^{\circ} 40^{\prime} 04.2^{\prime \prime} \mathrm{N} \\
78^{\circ} 58^{\prime} 33.9^{\prime \prime} \mathrm{E}\end{array}$ & 0.01219 & 0.01233 & 0.02452 \\
\hline 20 & Soliakudy & $\begin{array}{l}9^{\circ} 42^{\prime} 48.5 ” \mathrm{~N} \\
78^{\circ} 59^{\prime} 59.5 \text { ' } \mathrm{E}\end{array}$ & 0.01234 & 0.01309 & 0.02543 \\
\hline 21 & Thondi & $\begin{array}{l}9^{\circ} 44^{\prime} 23.1 ” \mathrm{~N} \\
79^{\circ} 01^{\prime} 10.8^{\prime \prime} \mathrm{E}\end{array}$ & 0.01046 & 0.01308 & 0.02354 \\
\hline 22 & Periyavalasaipatinam & $\begin{array}{l}9^{\circ} 46^{\prime} 01.2 ” \mathrm{~N} \\
79^{\circ} 02^{\prime} 37.5^{\prime} \mathrm{E}\end{array}$ & 0.0096 & 0.01777 & 0.02737 \\
\hline 23 & Passipatnam & $\begin{array}{l}9^{\circ} 48^{\prime} 36.2 ” \mathrm{~N} \\
79^{\circ} 40^{\prime} 48.4 \text { ' } \mathrm{E}\end{array}$ & 0.007434 & 0.00811 & 0.015544 \\
\hline 24 & S. P. Patnam & $\begin{array}{l}9^{\circ} 50^{\prime} 69.0 ” \mathrm{~N} \\
79^{\circ} 06^{\prime} 10.2^{\prime \prime} \mathrm{E}\end{array}$ & 0.01253 & 0.02465 & 0.03718 \\
\hline 25 & Kumarappanvayal & $\begin{array}{l}9^{\circ} 56^{\prime} 70.3^{\prime \prime} \mathrm{N} \\
79^{\circ} 09^{\prime} 22.2^{\prime \prime} \mathrm{E}\end{array}$ & 0.0096 & 0.0096 & 0.0192 \\
\hline 26 & Kottaipatnam & $\begin{array}{l}9^{\circ} 58^{\prime} 58.1 ” \mathrm{~N} \\
79^{\circ} 12^{\prime} 16.1 \text { 'E }\end{array}$ & 0.01163 & 0.01208 & 0.02371 \\
\hline 27 & Ammapatnam & $\begin{array}{l}10^{\circ} 00^{\prime} 39.9^{\prime \prime} \mathrm{N} \\
79^{\circ} 13^{\prime} 44.7^{\prime \prime} \mathrm{E}\end{array}$ & 0.00636 & 0.00737 & 0.01373 \\
\hline 28 & Kodiakarai & $\begin{array}{l}10^{\circ} 02^{\prime} 28.8^{\prime \prime} \mathrm{N} \\
79^{\circ} 15^{\prime} 41.3^{\prime \prime} \mathrm{E}\end{array}$ & 0.01508 & 0.00808 & 0.02316 \\
\hline 29 & Manamelkudy & $\begin{array}{l}10^{\circ} 03^{\prime} 84.3^{\prime \prime} \mathrm{N} \\
79^{\circ} 14^{\prime} 64.2^{\prime \prime} \mathrm{E}\end{array}$ & 0.01393 & 0.00844 & 0.02237 \\
\hline 30 & Kattumavadi & $\begin{array}{l}10^{\circ} 08^{\prime} 09.5^{\prime \prime} \mathrm{N} ; 79^{\circ} \\
13^{\prime} 40.5^{\prime} \mathrm{E}\end{array}$ & 0.10844 & 0.18735 & 0.29579 \\
\hline 31 & Kazhumankuda & $\begin{array}{l}10^{\circ} 14^{\prime} 36.1 \text { ”N; } \\
79^{\circ} 16^{\prime} 36.8^{\prime \prime} \mathrm{E}\end{array}$ & 0.01661 & 0.00991 & 0.02652 \\
\hline \multirow[t]{2}{*}{32} & Manora Light House & $\begin{array}{l}10^{\circ} 15^{\prime} 57.6 ” \mathrm{~N} \\
79^{\circ} 18^{\prime} 15.2 ” \mathrm{E}\end{array}$ & 0.0061857 & 0.0186 & 0.0247857 \\
\hline & Mean $\pm \mathrm{SE}$ & & $0.0165417 \pm 0.023$ & $0.02231 \pm 0.041$ & $0.03885615 \pm 0.064$ \\
\hline
\end{tabular}

Table 3. Blue carbon sink (Tg C) of seagrass meadows in Gulf of Mannar and Palk Bay

\begin{tabular}{lll}
\hline Indices & Gulf of Mannar & Palk Bay \\
\hline Soil carbon density of two cores upto $20 \mathrm{~cm}^{-1 e p t h}\left(\mathrm{~g} \mathrm{C} \mathrm{cm}^{-2}\right.$, Mean $\left.\pm \mathrm{SE}\right)$ & $0.0034472 \pm 0.002$ & $0.03885615 \pm 0.064$ \\
When converted to per ha $\left(\mathrm{gC} \mathrm{ha}^{-1}\right)$ & 344720 & 3885615 \\
Total area under seagrass cover (ha) & 5170.66 (Tangaradjou and Bhatt, 2018) & 11323 (Susila et al., 2012) \\
Blue carbon sink (Tg C) & 0.001782 & 0.043996 \\
\hline
\end{tabular}

change mitigation and emphasises the need to conserve these underwater meadows from further deterioration. This study provides baseline quantitative data on blue carbon stock of seagrass meadows of Gulf of Mannar and Palk Bay and the annual increment of carbon being sequestered by seagrass meadows can be inferred from future assessments in the years to come. Any fluctuation from this base value during subsequent observations can indicate the status of health of these fragile ecosystems.

\section{Acknowledgements}

The authors are thankful to the ICAR, Govt. of India, New Delhi for the financial support and to the NICRA project of ICAR-CMFRI, Kochi for the facilities received. 


\section{References}

Bedulli, C., Lavery, P. S., Harvey, M., Duarte, C. M. and Serrano, O. 2020. Contribution of seagrass blue carbon toward carbonneutralpoliciesinatouristicandenvironmentally-friendly island. Front. Mar. Sci., 7(1). https://doi.org/10.3389/fmars. 2020.00001

Banerjee, K., Paneerselvam, A., Ramachandran, P., Ganguly, D., Singh, G. and Ramesh, R. 2018. Seagrass and macrophyte mediated $\mathrm{CO}_{2}$ and $\mathrm{CH}_{4}$ dynamics in shallow coastal waters. PLoS ONE, 13(10): e0203922. https://doi.org/10.1371/ journal.pone.0203922.

Duarte, C. M., Middleburg, J. J. and Caraco, N. 2005. Major role of marine vegetation on the oceanic carbon cycle. Biogeosciences, 2: 1-8. https://doi.org/10.5194/bg-2-1-2005.

Fourqurean, J. W., Duarte, C. M., Kennedy, H., Marba, N. and Holmer, M. 2012. Seagrass ecosystems as a globally significant carbon stock. Nat. Geosci., 5: 505-509. doi:10. 1038/NGEO1477.

Greiner, J. T., McGlathery, K. J., Gunnell, J. and McKee, B. A. 2013. Seagrass restoration enhances "Blue Carbon" sequestration in coastal waters. PLoS ONE, 8(8): e72469. https://doi.org/10.1371/journal.pone.0072469.

Jones, R. J., Hiederer, R., Rusco, E. and Montanarella, L. 2005. Estimating organic carbon in the soils of Europe for policy support. Eur. J. Soil Sci., 56: 655-671. http://dx.doi. org/10.1111/j.1365-2389.2005.00728.x.

Kaladharan, P. and Anasukoya, A. 2019. Shrinking seagrass meadows - Observations from four Lagoons of Laccadive Archipelago. J. Mar. Boil. Ass. India, 61(2): 47-50.

Kannan, L., Thangaradjou, T. and Anantharaman, P. 1999. Status of seagrasses of India. Seaweed Res. Util., 21(1\&2): 25-33.

Lavery, P. S., Mateo, M., Serrano, O. and Rozaimi, M. 2013. Variability in the carbon storage of seagrass habitats and its implications for global estimates of blue carbon ecosystem service. Plos ONE, 8, e73748, doi:10.1371/ journal.pone.0073748.

Lavery, P. S., Mateo, M., Serrano, O. and Rozaimi, M. 2013. Variability in the carbon storage of seagrass habitats and its implications for global estimates of blue carbon ecosystem service. Plos ONE, 8, e73748, doi:10.1371/ journal.pone.0073748.

Lakshmanan, K. K. and Rajeswari, S. 1982. The new record of Thalassia hemprichii (Ehrenb.) Aschers, from the main coast of India. Curr. Sci., 51: 373-374.
Serrano, O., Alinahasheer, H., Duarte, C. M. and Irigoien, X. 2018. Carbon stocks and accumulation rates in Red Sea seagrass meadows. Sci. Rep., 8: 15037. doi: 10.1038/ s41598-018-33182-8.

Serrano, O., Lovelock, C. E., B Atwood, T., Macreadie, P. I., Canto, R., Phinn, S., Arias-Ortiz, A., Bai, L., Baldock, J., Bedulli, C., Carnell, P., Connolly, R. M., Donaldson, P., Esteban, A., Ewers Lewis, C. J., Eyre, B. D., Hayes, M. A., Horwitz, P., Hutley, L. B., Duarte, C. M. 2019. Australian vegetated coastal ecosystems as global hotspots for climate change mitigation. Nature Communications, 10(1): 1-10.

Susila, S., Nobi, E., Thangaradjou, T., Sivakumar, K., Anantharaman, P., Kannan, L. and Balasubramanian, T. 2012. In situ biomass estimation of seagrasses in the Gulf of Mannar (India) and their areal coverage using IRS P6 LISS III. In: Sridhar, K. (Ed.), Aquatic plants and plant diseases: Types. characteristics and management. NOVO Science Publishers, New York, USA, p. 209-226.

Terrados, J. and Borum, J. 2004. Why are seagrasses important? Goods and services provided by seagrass meadows. In: Jens Borum, Duarte, M., Jensen, D. K. and Greve, T. M. M. (Eds.), European seagrasses: An introduction to monitoring and management. The M and M. S. Project, p. 8-10.

Thangaradjou, T. and Bhatt, J. R. 2018. Status of seagrass ecosystems in India. Ocean Coast. Manag., 159: 7-15. https://doi.org/10.1016/j.ocecoaman.2017.11.025.

Unsworth, L. C. and Unsworth, R. 2013. Seagrass meadows, ecosystem services and sustainability. Environment: Science and Policy for Sustainable Development, 55(3): 14-28. https://doi.org/10.1080/00139157.2013.785864.

UNESCO.ORG. Gulf of Mannar Biosphere Reserve, India. En.unesco.org $>$ biosphere $>$ aspac $>$ gulf of mannar. (Accessed 17 October 2020).

UNDESA 2020 SDG Good Practices: A compilation of success stories and lessons learnt in SDG implementation, $1^{\text {st }} \mathrm{edn}$. sdg.un.org.

Walkley, A. and Black, I. A. 1934. An examination of degtjiareff method for determination of soil organic matter and a proposed modification of the chromic acid titration method. Soil Sci., 37: 29-37. DOI: 10.1097/00010694-19340100000003.

Waycott, M., Duarte, C. M., Carruthers, T. J., Orth, R. J., Dennison, W. C. and Olyarnik, S. 2009. Accelerating loss of seagrasses across the globe threatens coastal ecosystems. Proc. Natl. Acad. Sci. U. S. A., 106: 12377-12381. doi:10. 1073/pnas.0905620106. 